\title{
THE INTRADERMAL SALT TEST IN FEVER
}

\author{
BY CHARLES W. DUDEN AND DAVID P. BARR
}

(From the Department of Medicine of Washington University and the Barnes Hospital, St. Louis)

(Received for publication January 2, 1930)

In 1923, McClure and Aldrich (1) (2) introduced the intradermal salt test in the study of nephritis. They injected $0.2 \mathrm{cc}$. normal saline solution intradermally into the deltoid region and found that it had a rather constant disappearance time in normal individuals and a greatly diminished disappearance time in nephritics. Various factors which might influence the test have been extensively studied. White and Irvine-Jones (3) have shown that the disappearance time is not affected by the $\mathrm{H}$-ion concentration, the osmotic pressure or the salt balance of the injected fluid. Neither the blood flow through the injected part nor the immersion of the injected extremity in hot or cold water have any notable effect. The disappearance time is not influenced by the concentration of nonprotein nitrogen, cholesterol or sodium chloride in the blood plasma. It is, however, definitely diminished by injecting minute amounts of adrenalin with the salt solution or by the direct application of cold to the local area of injection. Circulatory stasis does not influence it but inadequate arterial blood supply may be of importance. Cohen (4) (5) (6) believes that the test affords an excellent means of determining the level of faulty circulation of a diseased extremity.

Because of the disturbance of both salt and water metabolism in pneumonia and possibly in other acute infections, it occurred to us that the intradermal salt test might be considerably affected during fever of bacterial origin. In the literature, we have found only one study which seems to offer any answer to this question. Harrison (7) tried the test during the course of lobar pneumonia in children and concluded that there was a shortening of the disappearance time of intradermally injected salt solution during the febrile stage of the disease. She found that the crisis had no immediate effect upon the 
test and that there was a slow return to a normal state following the crisis. She concluded that the change in the disappearance time indicated an intoxication of the tissues which persisted for some tıme following the crisis.

Our tests were conducted according to the technique advised by McClure and Aldrich and always performed by the same observer. The normal saline solution was injected intradermally in $0.2 \mathrm{cc}$. quantities and the time of disappearance was determined by palpation.

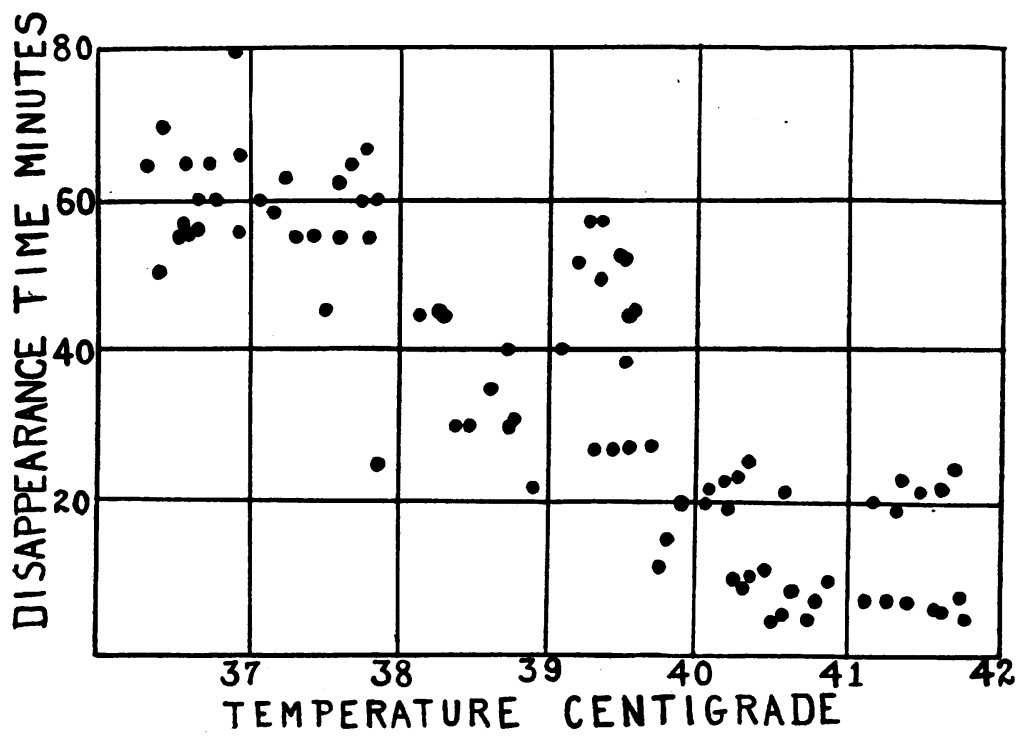

Chart 1. The Disappearance Tume of Intradermally Injected Saline at Different Temperature Levels during Bacterial Fever and Fever Following the Injection of Foreign Protein

The disappearance time of normal individuals ranged from 58-60 to 70-75 minutes. The tests upon patients were usually comparative, using the normal or the subnormal temperature of the individual as the base line control. A large number of tests were done on fevered patients on whom no controls could be obtained. Although these usually showed a definitely shortened disappearance time, they have not been included in these tables. Chart 1 shows graphically the disappearance time at all temperatures which were tested. There will be seen variations of considerable degree but in general the gradient is 
TABLE 1

The influence of fever of bacterial origin upon the disappearance time of intradermally injected salt solution

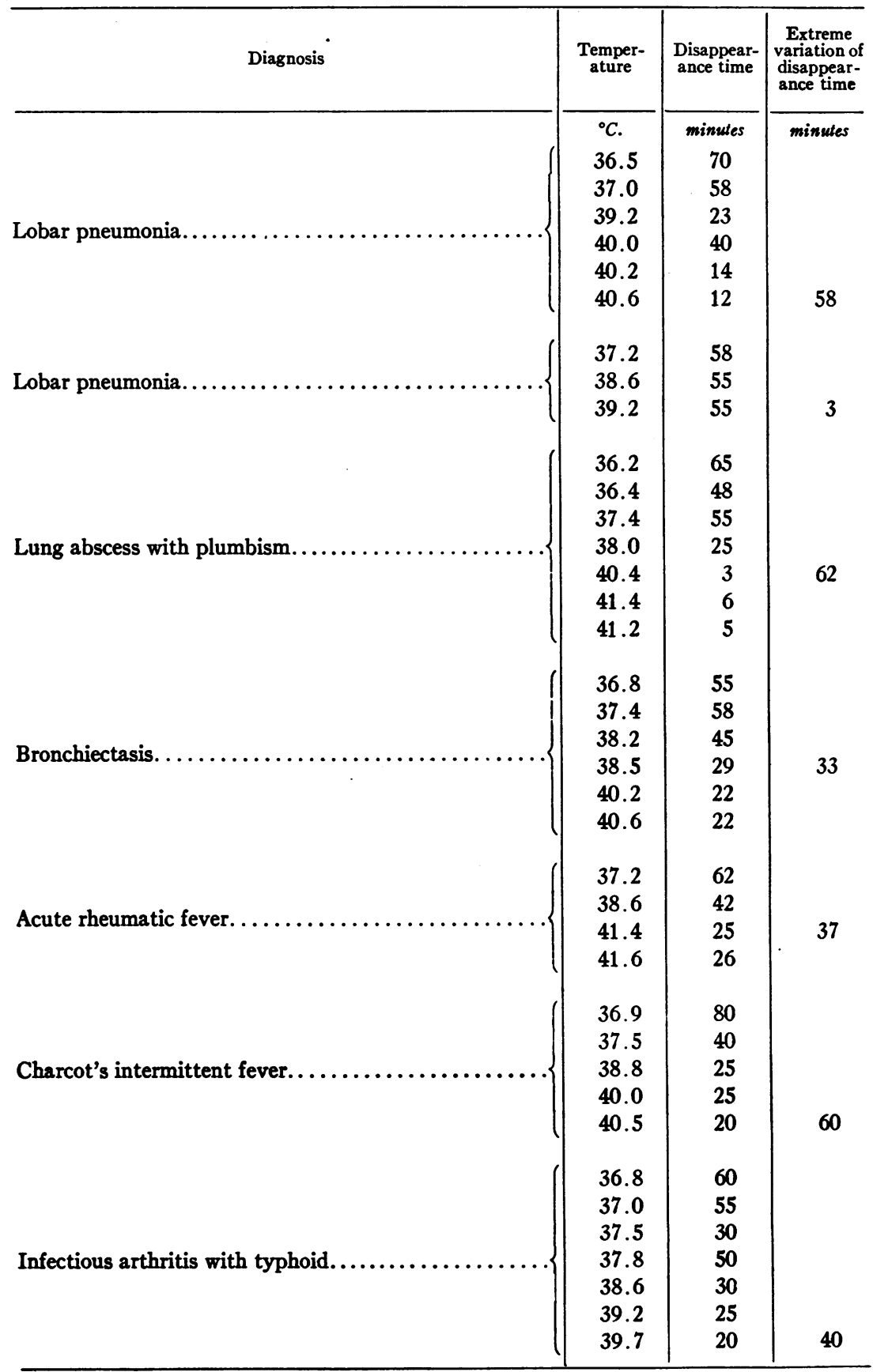




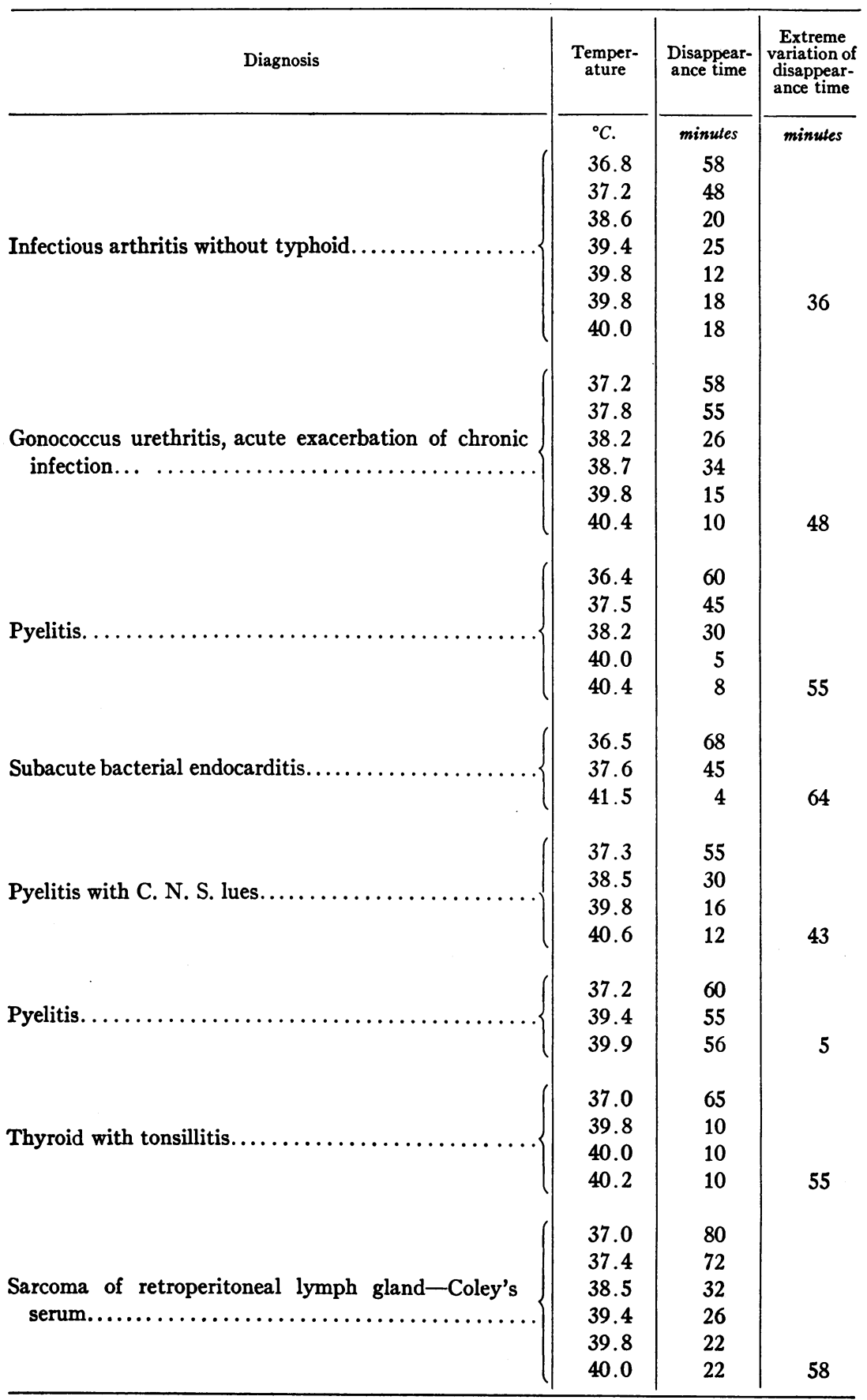




\begin{tabular}{|c|c|c|c|c|}
\hline Diagnosis & $\cdot$ & $\begin{array}{l}\text { Temper- } \\
\text { ature }\end{array}$ & $\begin{array}{l}\text { Disappear- } \\
\text { ance time }\end{array}$ & $\begin{array}{c}\text { Extreme } \\
\text { variation of } \\
\text { disappear- } \\
\text { ance time }\end{array}$ \\
\hline Pelvic inflammatory process..... & $\ldots \ldots \ldots \ldots \ldots \ldots$ & $\begin{array}{l}{ }^{\circ} \mathrm{C} . \\
37.0 \\
37.8 \\
38.9 \\
40.0\end{array}$ & $\begin{array}{c}\text { minutes } \\
\mathbf{5 8} \\
\mathbf{5 5} \\
\mathbf{5 5} \\
\mathbf{5 6}\end{array}$ & 3 \\
\hline
\end{tabular}

quite definite showing a very short disappearance time with high temperature and a normal or only slightly changed disappearance time with mild degrees of temperature.

Observations were made on cases of pyelitis, lung abscess, bronchiectasis, acute rheumatic fever, urethritis and other specific infections. In addition tests were performed on cases in whom foreign protein (typhoid vaccine) was injected intravenously. In table 1 there are assembled all of the tests which were performed upon patients with infections or with temperature reaction following the injection of foreign protein. Eighty observations were made in sixteen individuals. The temperature ranged from $36^{\circ}$ to $40.5^{\circ}$. In thirteen patients, a higher temperature was accompanied by a more rapid disappearance of the injected saline, the difference in one instance being as great as 60 minutes. In three instances there was no corresponding change in disappearance time with rising temperature. One of these occurred in a patient with pneumonia who had on one occasion almost the same disappearance time with a temperature of $39.2^{\circ}$ as with a temperature of $37.2^{\circ}$. Another was a case of pyelitis which showed practically no change in disappearance time with temperature ranging from $37.2^{\circ}$ to $39.9^{\circ}$. The third case showed little difference with temperature of $37.4^{\circ}$ and $40.0^{\circ}$ respectively. In the last two cases the condition of the skin made the determination by palpation extremely difficult.

The test has also been applied to a second group of cases in which fever was produced by external heat. The patients were paretics to whom temperature baths were given for therapeutic purposes. In each case, there was a normal temperature at the beginning of the bath. The patient was immersed in water to the shoulders and the tempera- 
ture of the water gradually increased, with corresponding temperature increase as shown on the chart. Table 2 shows the result of 20 observations on four patients in whom the temperature ranged from $37^{\circ}$ to $41^{\circ} \mathrm{C}$. The patients usually maintained some fever $\left(38^{\circ}\right)$ one hour after the bath was stopped, a circumstance which permitted complete observation of the injected areas at an abnormal temperature level. The results are recorded in table 2. In none of these observations was there any change in disappearance time with rising temperature.

TABLE 2

Results of intradermal salt test, the fever induced by hot baths

\begin{tabular}{|c|c|c|c|c|c|c|c|}
\hline Diagnosis & 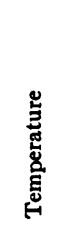 & 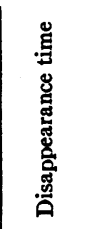 & 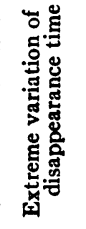 & Diagnosis & 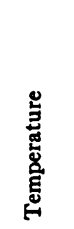 & 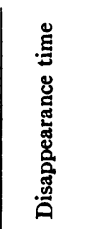 & 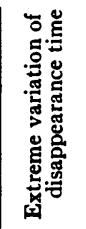 \\
\hline $\begin{array}{l}\text { C.N.S. lues with hot } \\
\text { baths }\end{array}$ & ${ }^{\circ} \mathrm{C}$. & minutes & minutes & $\begin{array}{l}\text { C.N.S. lues with hot } \\
\text { baths }\end{array}$ & ${ }^{\circ} \mathrm{C}$. & minutes & minutes \\
\hline (1) & $\begin{array}{l}37.2 \\
38.8 \\
38.6 \\
39.9\end{array}$ & $\begin{array}{l}62 \\
58 \\
58 \\
58\end{array}$ & 4 & (3) & $\begin{array}{l}37.2 \\
37.3 \\
39.5 \\
40.0\end{array}$ & $\begin{array}{l}60 \\
60 \\
55 \\
55\end{array}$ & 5 \\
\hline (2) & $\begin{array}{l}37.2 \\
39.2 \\
39.2 \\
39.8\end{array}$ & $\begin{array}{l}60 \\
58 \\
58 \\
56\end{array}$ & 4 & (4) & $\begin{array}{l}37.1 \\
40.0 \\
40.0 \\
41.0\end{array}$ & $\begin{array}{l}60 \\
58 \\
56 \\
58\end{array}$ & 2 \\
\hline
\end{tabular}

From these experiments it was demonstrated that change in the disappearance time of intradermally injected salt solution was not dependent upon high temperature as such. On the other hand, the test was always affected by bacterial fever whether this was produced by vaccine or by spontaneous infection.

It seemed of interest to study some clinical fever in which bacterial invasion was not demonstrable. For the purpose we selected the fever which often follows thyroidectomy in toxic goitre. In this condition sometimes designated as thyroid crisis, there occurs a few hours following the operation, a startling temperature rise, sometimes an extreme 
hyperpyrexia. It has been suggested that the state results from the introduction into the circulation of an excessive amount of thyroid secretion caused perhaps by the manipulation of the gland at the time of operation. No infection can be shown and no leucocytosis or other sign of bacterial invasion is evident.

Fourteen thyroid cases were studied. All of them had after the operation of thyroidectomy a high fever with rapid pulse but without

TABLE 3

The influence of fever of thyroid crisis upon the disappearance time of intradermally injected salt solution

\begin{tabular}{|c|c|c|c|c|c|c|c|}
\hline Case & Temperature & $\begin{array}{l}\text { Disappear- } \\
\text { ance time }\end{array}$ & $\begin{array}{c}\text { Extreme } \\
\text { variation of } \\
\text { disappear- } \\
\text { ance time }\end{array}$ & Case & Temperature & $\begin{array}{l}\text { Disappear- } \\
\text { ance time }\end{array}$ & $\begin{array}{c}\text { Extreme } \\
\text { variation of } \\
\text { disappear- } \\
\text { ance time }\end{array}$ \\
\hline & ${ }^{\circ} \mathrm{C}$ & minutes & minutes & & ${ }^{\circ} \mathrm{C}$. & minutes & minutes \\
\hline 1 & $\begin{array}{l}37.2 \\
40.0\end{array}$ & $\begin{array}{l}63 \\
59\end{array}$ & 4 & 8 & $\begin{array}{l}37.0 \\
38.6\end{array}$ & $\begin{array}{l}65 \\
65\end{array}$ & 0 \\
\hline 2 & $\begin{array}{l}37.2 \\
39.0\end{array}$ & $\begin{array}{l}50 \\
25\end{array}$ & 25 & 9 & $\begin{array}{l}37.0 \\
39.0\end{array}$ & $\begin{array}{l}62 \\
65\end{array}$ & -3 \\
\hline 3 & $\begin{array}{l}37.0 \\
39.2\end{array}$ & $\begin{array}{l}68 \\
65\end{array}$ & 3 & 10 & $\begin{array}{l}37.0 \\
39.4\end{array}$ & $\begin{array}{l}85 \\
90\end{array}$ & -5 \\
\hline 4 & $\begin{array}{l}37.2 \\
39.6\end{array}$ & $\begin{array}{l}58 \\
22\end{array}$ & 36 & 11 & $\begin{array}{l}37.0 \\
38.5\end{array}$ & $\begin{array}{l}60 \\
55\end{array}$ & 5 \\
\hline 5 & $\begin{array}{l}37.0 \\
38.6\end{array}$ & $\begin{array}{l}55 \\
55\end{array}$ & 0 & 12 & $\begin{array}{l}37.0 \\
39.0\end{array}$ & $\begin{array}{l}62 \\
65\end{array}$ & -3 \\
\hline 6 & $\begin{array}{l}37.0 \\
39.6\end{array}$ & $\begin{array}{l}65 \\
65\end{array}$ & 0 & 13 & $\begin{array}{l}37.0 \\
40.5\end{array}$ & $\begin{array}{l}55 \\
45\end{array}$ & -5 \\
\hline 7 & $\begin{array}{l}37.0 \\
40.0\end{array}$ & $\begin{array}{l}65 \\
65\end{array}$ & 0 & & & & \\
\hline
\end{tabular}

recognizable focus of infection. In no instance did the leucocyte count rise above 12,000 . In two the disappearance time was definitely affected. In eleven, however, no change in the disappearance time could be noted. Case 7 offers a striking contrast between the reaction occurring in bacterial fever and the fever of thyroid crisis. With normal temperature her disappearance time was 60 minutes. While 
she was being prepared for operation, she developed an acute follicular tonsilitis with a temperature of $40^{\circ} \mathrm{C}$. and had coincidentally a disappearance time of ten minutes. (See table 1.) Immediately after operation she developed a mild thyroid crisis with a temperature of $40^{\circ} \mathrm{C}$. and a disappearance time of 55-60 minutes. Table 3 shows the range in temperature and the disappearance time of injected saline in the patients with thyroid crisis. While the results are not entirely uniform, it is evident that the disappearance time is less affected than in cases with fever of bacterial or foreign protein origin.

SUMMARY

1. The disappearance time of intradermally injected salt solution has been studied in different types of fever. The fever of infectious disease and that following the injection of foreign protein, causes a marked reduction in the disappearance time.

2. Fever caused by external heat in the form of hot immersion baths has no effect on the disappearance time.

3. Fever following thyroidectomy in toxic goitre (thyroid crisis) usually has no effect on the disappearance time of injected saline.

\section{BIBLIOGRAPHY}

1. McClure, W. B., and Aldrich, C. A., J. Am. Med. Assoc., 1923, lxxxi, 293. Time Required for Disappearance of Intradermally Injected Salt Solution.

2. Aldrich, C. A., and McClure, W. B., J. Am. Med. Assoc., 1924, Ixxxii, 1425. The Intradermal Salt Solution Test. II. Its Prognostic Value in "Nephritis" with Generalized Edema.

3. White, H. L., and Irvine-Jones, E., Am. Heart J., 1927, ii, 517. Factors Affecting the Disappearance Time of Intradermal Injections.

4. Cohen, M. B., J. Am. Med. Assoc., 1925, lxxxiv, 1561. The Intracutaneous Salt Solution Test.

5. Cohen, M. B., Applebaum, H. S., and Hainsworth, E. L., J. Am. Med. Assoc., 1926, Ixxxvi, 1677. The Intracutaneous Salt Solution Test. Its Use as a Test of the Efficiency of the Circulation in the Extremities.

6. Stern, W. G., and Cohen, M. B., J. Am. Med. Assoc., 1926, Ixxxvii, 1355. The Intracutaneous Salt Solution Wheal Test. Its Value in Disturbances of the Circulation in the Extremities.

7. Harrison, J., J. Am. Med. Assoc., 1925, lxxiv, 1258. Intradermal Salt Solution Test in Lobar Pneumonia in Children. 